\title{
Death receptor-induced apoptotic and necrotic cell death: differential role of caspases and mitochondria
}

\author{
G Denecker ${ }^{1,3}$, D Vercammen ${ }^{1}, M_{\text {Steemans }}{ }^{1}$, \\ T Vanden Berghe ${ }^{1}$, G Brouckaert ${ }^{1}, \mathrm{G}$ Van Loo', \\ B Zhivotovsky ${ }^{2}$, W Fiers ${ }^{1}$, J Grooten ${ }^{1}$, W Declercq ${ }^{1}$ and \\ $P$ Vandenabeele ${ }^{\star, 1}$ \\ 1 Molecular Signaling and Cell Death Unit, Department of Molecular Biology, \\ Flanders Interuniversity Institute for Biotechnology and Ghent University, 9000 \\ Gent, Belgium \\ 2 Institute of Environmental Medicine, Division of Toxicology, Karolinska \\ Institute, 17177 Stockholm, Sweden \\ ${ }^{3}$ Current address: Microbial Pathogenesis Unit, Catholic University of Louvain, \\ 1200 Brussels, Belgium \\ * Corresponding author: P Vandenabeele, Department of Molecular Biology, \\ Flanders Interuniversity Institute for Biotechnology and Ghent University, \\ K.L. Ledeganckstraat 35, B-9000 Gent, Belgium. Tel: 32-9-2648716. \\ Fax: 32-9-2645348. E-mail: peter.vandenabeele@dmb.rug.ac.be
}

Received 5.3.01; accepted 27.3.01

Edited by J Tschopp

\begin{abstract}
In L929sAhFas cells, tumor necrosis factor (TNF) leads to necrotic cell death, whereas agonistic anti-Fas antibodies elicit apoptotic cell death. Apoptosis, but not necrosis, is correlated with a rapid externalization of phosphatidylserine and the appearance of a hypoploid population. During necrosis no cytosolic and organelle-associated active caspase- 3 and -7 fragments are detectable. The necrotic process does not involve proteolytic generation of truncated Bid; moreover, no mitochondrial release of cytochrome $c$ is observed. Bcl-2 overexpression slows down the onset of necrotic cell death. In the case of apoptosis, active caspases are released to the culture supernatant, coinciding with the release of lactate dehydrogenase. Following necrosis, mainly unprocessed forms of caspases are released. Both TNFinduced necrosis and necrosis induced by anti-Fas in the presence of the caspase inhibitor benzyloxycarbonyl-Val-AlaAsp(OMe)-fluoromethylketone are prevented by the serine protease inhibitor $\mathrm{N}$-tosyl-L-phenylalanine chloromethylketone and the oxygen radical scavenger butylated hydroxyanisole, while Fas-induced apoptosis is not affected. Cell Death and Differentiation (2001) 8, 829-840.
\end{abstract}

Keywords: apoptosis; necrosis; death receptors; caspases; mitochondria

Abbreviations: Ac-DEVD-amc, acetyl-Asp(OMe)Glu(OMe)-ValAsp(OMe)-aminomethylcoumarin; Ac-YVAD-amc, acetyl-Tyr-ValAla-Asp-aminomethylcoumarin; AK, adenylate kinase; Apaf-1, apoptotic protease-activating factor-1; BHA, butylated hydroxyanisole; CAF, caspase-activated factor; CMTMros, chloromethyltetramethylrosamine; DD, death domain; EMAP II, endothelial monocyte-activating polypeptide II; FADD, Fas-associated DD; FITC, fluorescein isothiocyanate; LDH, lactate dehydrogenase; MTT, 3-(4,5-dimethylthiazol-2-yl)-2,5-diphenyltetrazoliumbromide; $\mathrm{PI}$, propidium iodide; PS, phosphatidylserine; R123, rhodamine 123; ROS, reactive oxygen species; tBid, truncated Bid; TLCK, Ntosyl-L-lysine chloromethylketone; TNF, tumor necrosis factor; TNF-RI, p55 TNF receptor; TPCK, N-tosyl-L-phenylananine chloromethylketone; zVAD-fmk, benzyloxycarbonyl-Val-AlaAsp(OMe)-fluoromethylketone; $\Delta \Psi_{\mathrm{m}}$, mitochondrial transmembrane potential

\section{Introduction}

There are two prototype ways for a cell to die, namely apoptosis and necrosis. Apoptosis is a highly conserved process than can be induced by a variety of physiological or pathological conditions and in which caspases and mitochondria plays a crucial role. Except for the death domain (DD) receptors, the molecular mechanisms by which the many different proapoptotic stimuli (such as irradiation, chemotherapeutics or growth factor depletion), signal and initiate mitochondrial changes, are currently not well understood. ${ }^{1,2}$ Clustering of Fas (CD95) by its natural ligand or by agonistic antibodies results in formation of a death-inducing signaling complex, consisting of the adapter protein Fas-associated DD $(\mathrm{FADD})^{3}$ and procaspase-8. ${ }^{4}$ Dimerization of procaspase- 8 is sufficient to generate mature caspase- $8 .{ }^{5}$ Apoptotic cell death is accompanied by a decrease in mitochondrial transmembrane potential $\left(\Delta \Psi_{\mathrm{m}}\right)$ and release of cytochrome $c$ from the mitochondrial intermembrane space. ${ }^{6}$ Recently, molecular links have been identified between early procaspase-8 activation by DD receptor aggregation and mitochondrial events. It was demonstrated that cytochrome $c$ release and decrease in $\Delta \Psi_{\mathrm{m}}$ is mediated by caspase-8-dependent proteolysis of $\mathrm{Bid}$, a proapoptotic member of the $\mathrm{Bcl}-2$ family ${ }^{7,8}$ or caspase-activated factor (CAF). ${ }^{9}$ The C-terminal proteolytic fragment of $\mathrm{Bid}$ is relocalized from the cytosol to the mitochondrial outer membrane to exert its proapoptotic function. ${ }^{7,8}$ Cytosolic cytochrome $c$, together with ATP/dATP, induces a conformation change in apoptotic proteaseactivating factor-1 (Apaf-1), allowing the latter to dimerize procaspase- 9 in a so-called apoptosome complex, which results in proteolytic activation of procaspase-9. ${ }^{10,11}$ Mature caspase- 9 in turn proteolytically activates the executioner caspase-3, which is also recruited in the apoptosome complex. $^{12}$

The exact mechanism of how cytochrome $c$ is released from the mitochondrial intermembrane space is currently unknown. Two models have been proposed. A first model states that cytochrome $c$ is released due to swelling of the mitochondrial matrix and subsequent disruption of the mitochondrial outer membrane. This might be caused by two different mechanisms: either opening of the mitochon- 
drial permeability transition pore in the inner membrane ${ }^{13}$ or mitochondrial hyperpolarization. ${ }^{14} \mathrm{~A}$ second model is based on the observation that $\mathrm{Bcl}-2$ family members regulate the release of cytochrome $c$ by their channel-forming capacity or my modulating the activity of existing channels. ${ }^{15}$ Irrespective of the mechanism implicated, the release of cytochrome $c$ has two important consequences: (i) activation of a caspase cascade by interaction of cytochrome $c$ with Apaf-1 and procaspase-9; ${ }^{10,11}$ (ii) inhibition of the mitochondrial electron transfer chain, resulting in reduced oxidative phosphorylation, promotion of production of reactive oxygen species (ROS) and finally (during secondary necrosis) impairment of cellular ATP production. $^{13}$

It is a generally accepted concept that apoptosis, in contrast to necrosis, does not lead to inflammation. This is only true when apoptotic cells are rapidly removed before the plasma membrane integrity is lost; the cellular content is spilled into the surrounding tissue during secondary necrosis. ${ }^{16}$ When massive apoptosis occurs or when the phagocytic activity is not sufficiently available to remove dying cells, inflammation and subsequent tissue damage become apparent, such as in renal ischemia-reperfusion injury. ${ }^{17,18}$ Until now, only endothelial monocyte-activating polypeptide II (EMAP II) has been identified as an apoptotic cell-derived molecule with proinflammatory and chemotactic properties. $^{19}$ EMAP II is generated via cleavage by caspase-7 of the p43 subunit of the tRNA synthetase complex. ${ }^{20}$ Here we report that caspases- 3 and -7 , involved in the execution of anti-Fas-induced apoptosis, are released in the cell culture supernatant during secondary necrosis.

It has recently become clear that, depending on the cellular context, either apoptotic or necrotic cell death will occur. The intensity of the same initial insult decides the prevalence of either apoptosis or necrosis. ${ }^{21-23}$ In addition, depletion of the cellular ATP content will convert an initially apoptotic stimulus in a necrotic one. ${ }^{24,25}$ Blocking the apoptotic pathway by caspase inhibitors or $\mathrm{Bcl}-2$ overexpression in many cases results in necrotic-like cell death. ${ }^{26,27}$ Furthermore, it was shown that enforced oligomerization of FADD in Jurkat cells pretreated with benzyloxycarbonyl-Val-Ala-Asp(OMe)-fluoromethylketone (zVAD-fmk) or deficient for caspase-8, resulted in necrotic cell death, while inducing apoptosis in normal Jurkat cells. ${ }^{28}$ Also anti-Fas-induced apoptosis in L929sAhFas cells is initially blocked by pretreatment with zVAD-fmk, but eventually reverts to necrosis. ${ }^{29}$ Thus the same cell death stimulus can result in apoptotic or necrotic cell death, depending whether caspases are activated or not. ${ }^{30}$ Recently, it was shown that DD receptor initiated necrosis in Jurkat clones is initiated by RIP in a caspaseindependent way but requiring the kinase activity of RIP. ${ }^{31}$ Another report identified the death effector domain of FADD as the adaptor molecule initiating direct necrotic signaling in Jurkat cells. ${ }^{32}$ In L929sA cells we have found that the DD of FADD has strong cytotoxic activity, while in apoptotically dying cells it functions as a dominant negative molecule. ${ }^{33}$ Less is known about the executioner program of necrotic cell death, although mitochondrial $\mathrm{ROS}^{30}$ and a variety of proteases have been implicated. ${ }^{34,35}$
In order to study possible differences in TNF- and antiFas-induced downstream cytotoxic necrotic and apoptotic pathways we compared a number of cell death parameters in L929sAhFas cells, viz. subcellular activation of procaspases, proteolytic activation of Bid, mitochondrial cytochrome $c$ release, protection by $\mathrm{Bcl}-2$ overexpression, influence of ROS scavengers and serine protease inhibitors. Our results indicate a differential role of caspases, mitochondrial ROS and serine proteases in necrotic and apoptotic cell death pathways. Furthermore, during anti-Fas-induced apoptosis, active caspases are released in the culture supernatant, which might operate in extracellular proteolytic cascades.

\section{Results}

\section{Time kinetic analysis of different cell death parameters during anti-Fas-induced apoptosis and TNF-induced necrosis}

L929sAhFas, stimulated with anti-Fas agonistic antibodies, die apoptotically, as morphologically characterized by membrane blebbing and nuclear condensation (Figure 1A); when exposed to TNF, these cells die from necrosis, as shown by the swollen cytoplasm (Figure 1E). In order to study in further detail both ways of dying of L929sAhFas cells, several cell death parameters were kinetically analyzed, such as PS exposure at the cell surface, caspase activation, decrease in $\Delta \Psi_{\mathrm{m}}$, DNA hypoploidy and cell membrane permeabilization. In apoptotic cells the sequence of events is maximal PS exposure (Figure 1B), coinciding with maximal DEVDase activity (Figure 1D), followed by a decrease in $\Delta \Psi_{\mathrm{m}}$ (Figure 1B), which coincides with DNA hypoploidy (Figure 1C). Finally, apoptotic cells lose plasma membrane integrity (Figure 1D). In the case of TNF-mediated necrosis, the kinetics of PS exposure, the decrease in $\Delta \Psi_{m}$ and the loss of plasma membrane integrity all coincide (Figure $1 \mathrm{~F}-\mathrm{H}$ ). It is not clear whether the annexin $\mathrm{V}$-positivity during necrosis is due to extracellular PS exposure or to intracellular detection of PS as a result of membrane permeabilization. ${ }^{36}$ Another distinctive parameter from apoptosis is the absence of induction of hypoploid DNA (Figure 1G) and the absence of caspase activity (Figure $1 \mathrm{H}$ ).

\section{Comparison of caspase activation between DD receptor-induced apoptosis and necrosis}

Next, we identified the procaspases processed during antiFas-induced apoptosis and checked whether any procaspases were processed during TNF-induced necrosis, since the possibility cannot be excluded that endogenous caspase inhibitors prevent their enzymatic activity. At different time intervals, cytosolic and organelle fractions of control, apoptotic and necrotic cells were prepared by digitonin treatment. As mature caspases- 3 and -7 are the major downstream executioners of the apoptotic process, ${ }^{37}$ we checked the appearance of proteolytic fragments of these caspases in apoptotic and necrotic conditions. Precursor forms of procaspases- 3 and -7 are detected both in the cytosolic and organelle fractions (Figure 2). The active p17 

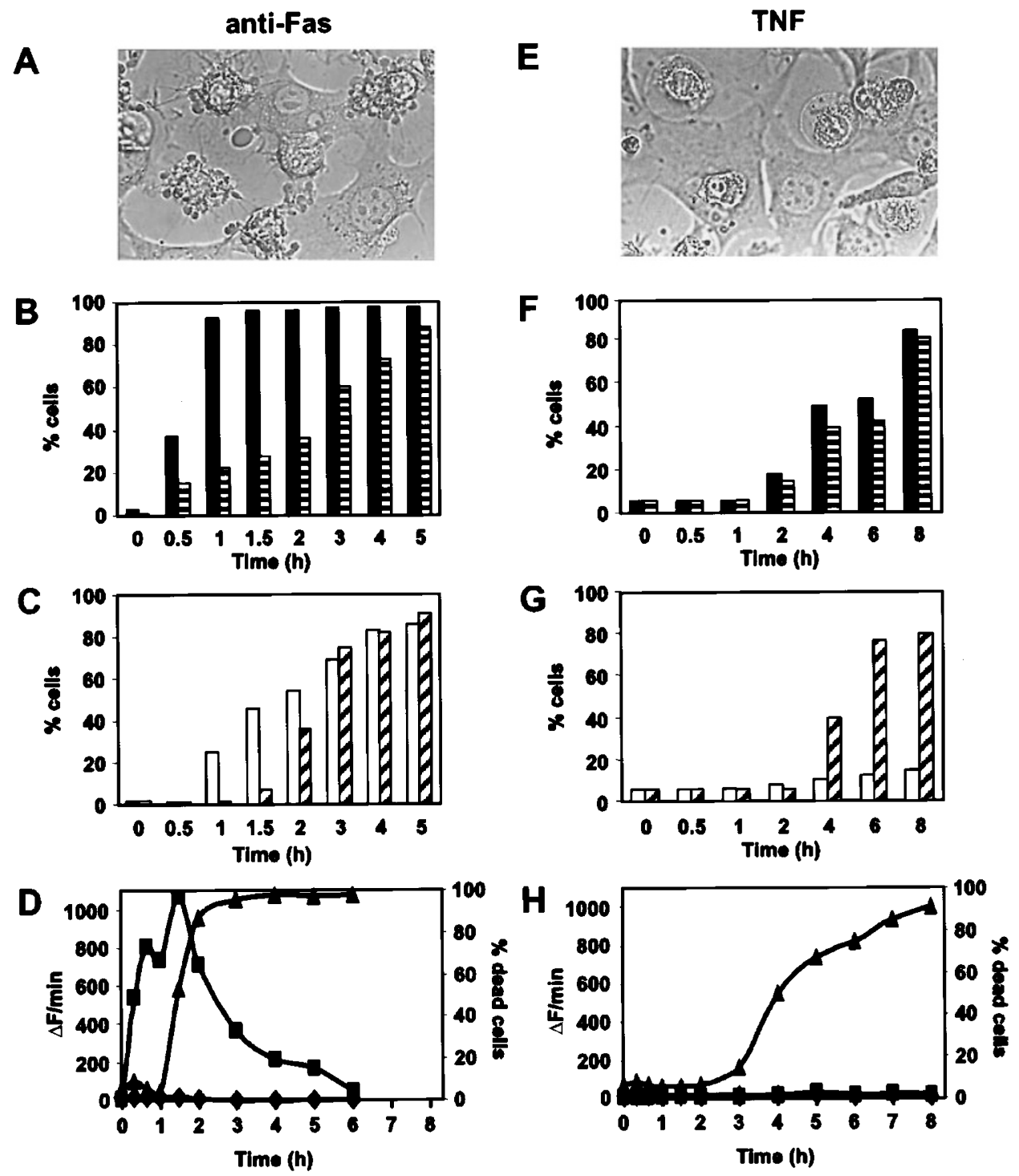

Figure 1 Time kinetic analysis of different cell death parameters during anti-Fas-induced apoptosis and TNF-induced necrosis (A, E) Morphological analysis of anti-Fas-induced apoptosis (1 h) and TNF-induced necrosis (5h). (B, F) Time kinetic analysis of the surface exposure of PS (percentage of annexin V-FITC-positive cells, black bars) and decrease in $\Delta \Psi_{m}$ (percentage of cells with decreased CMTMros staining, hatched bars). (C, G) Percentage of hypoploid cells (white bars) and loss of membrane integrity (percentage of PI-positive cells, hatched bars). (D, H) Time course of Ac-YVAD-amc ( $)$ ), and Ac-DEVD-amc ( $\mathbf{\square}$ ), cleavage activity compared with the percentage of cells that had lost plasma membrane integrity as determined with PI (percentage of cell death, $\mathbf{\Delta}$ ). Results are representative of three independent experiments

subunit of caspase-3 was first detected in the cytosol of antiFas-treated cells, and only $1 \mathrm{~h}$ later in the organelleassociated fraction (Figure 2A, B). Procaspase-7 was activated with similar time kinetics in apoptotic cytosol as compared to procaspase-3. Furthermore, in the organelle fraction the p19 subunit of caspase-7 occurred before the generation of processed caspase- 3 . In necrotic conditions no proteolysis of procaspases-3 or -7 was detectable (Figure 2D, E). In agreement with the proteolytic activation of procaspase3 , we observed a specific $115-84 \mathrm{kDa}$ cleavage of polyADP-ribosyl polymerase in apoptotic but not in necrotic cell lysates (data not shown).

During the late state of anti-Fas-induced apoptosis, i.e. when all cells have lost their plasma membrane integrity
(Figure 2C), the amount of procaspases and p20 subunits present in the cytosol decreases (Figure 2A). A similar decrease in cytosolic procaspases is observed during the late phase of TNF-induced necrosis (Figure 2D). In contrast, procaspase levels in the organelle fraction remained constant in both anti-Fas- and TNF-induced cell death (Figure 2B, E). Therefore, a time kinetic analysis was performed to analyze whether cytosolic procaspases and/or p20 subunits were released to the culture supernatant during late apoptotic and necrotic stages of cell death. In case of anti-Fas-induced apoptosis we found that the p20 subunit of both caspases- 3 and -7 and a small amount of procaspases- 3 and -7 were released to the culture supernatant (Figure $3 \mathrm{~A}, \mathrm{~B}$ ). Also during late TNF-induced 

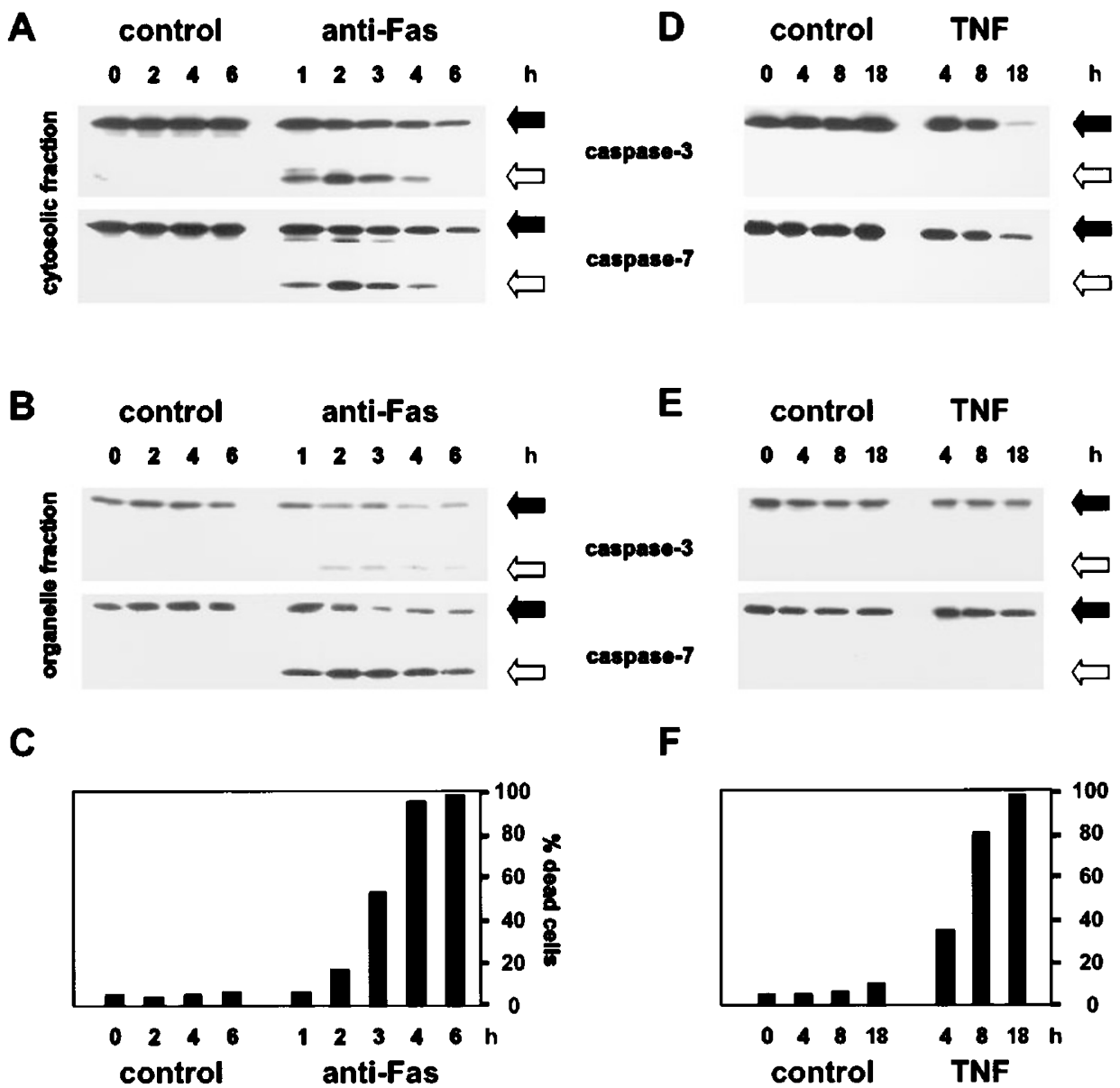

$\mathbf{F}$

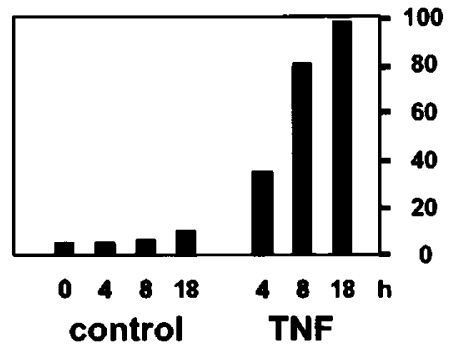

Figure 2 Time kinetic analysis of caspases-3 and -7 activation during anti-Fas-induced apoptosis and TNF-induced necrosis. Cytosolic fractions (A, D) and organelle fractions (B, E) were prepared and analyzed by PAGE and Western blotting. Open and closed arrows indicate processed p20 subunit and procaspase, respectively. The percentage of dead cells was determined by PI uptake $(\mathbf{C}, \mathbf{F})$

necrosis, procaspases were detected in the culture supernatant (Figure 3D, E). Next we investigated whether the release of subunits of caspases- 3 and -7 were enzymatically active on Ac-DEVD-amc fluorogenic substrate. As a control for release of cytosolic proteins and loss of plasma membrane integrity, the amount of LDH present in the culture supernatant was determined. As shown in Figure 3, during anti-Fas-induced apoptosis a vast Ac-DEVD-amc proteolytic activity in the culture supernatant coincided with LDH activity, suggesting a passive diffusion process of cytosolic proteins during necrosis and the secondary necrotic phase of the apoptotic process (Figure 3C, F). At later time points of TNF-induced necrotic cell death some p20-like fragments of caspases-3 and -7 appeared in the culture supernatant, resulting in minor DEVDase activity (Figure 3E, F).

\section{Proteolytic activation of Bid and release of cytochrome $c$ from the mitochondria during apoptosis and necrosis}

To analyze the role of mitochondria in death receptor-induced apoptosis and necrosis in L929sAhFas cells, the proteolytic activation of Bid and the release of cytochrome $c$ to the cytosol were determined. Western blot analysis of cytosolic and organelle fractions of untreated L929sAhFas cells revealed that p22 Bid was present in both cytosolic and organelle fractions (Figure 4A, D). Anti-Fas treatment resulted in an early cleavage of p22 Bid to a p15 tBid, only shortly and to a minor extent detectable in the cytosolic fraction; the vast majority of tBid was associated with the organelle fraction (Figure 4A). In necrotic cells, no cleavage of p22 Bid is detectable either in the cytosol or in the organelle fraction (Figure 4D). Only late in the necrotic process was a very small amount of tBid detectable in the organelle fraction. The appearance of tBid in the organelle fraction during anti-Fasinduced apoptosis coincides with the release of cytochrome $c$ to the cytosol (Figure 4B). However, although there was a clear decrease in amount of the cytochrome $c$ in the organelle fraction 4-6 $\mathrm{h}$ after anti-Fas treatment, we could not detect any cytochrome $c$ accumulation in the cytosol at these later time points. As was the case for caspases, we found that during secondary necrosis cytochrome $c$ accumulates in the culture supernatant (Figure 4B). TNF-induced necrosis did not result in a detectable release of cytochrome $c$ in the cytosol. However, in the late necrotic phase of TNF-stimulated cells, 
A

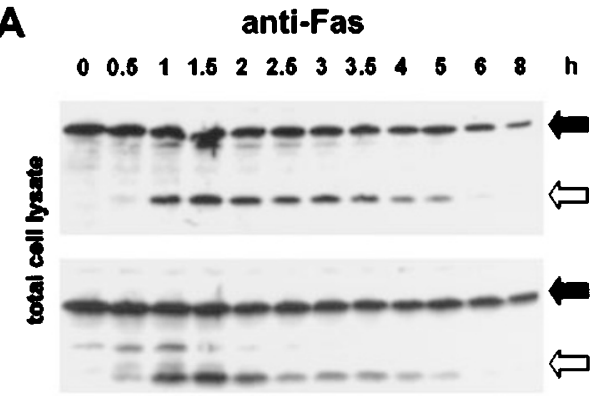

B
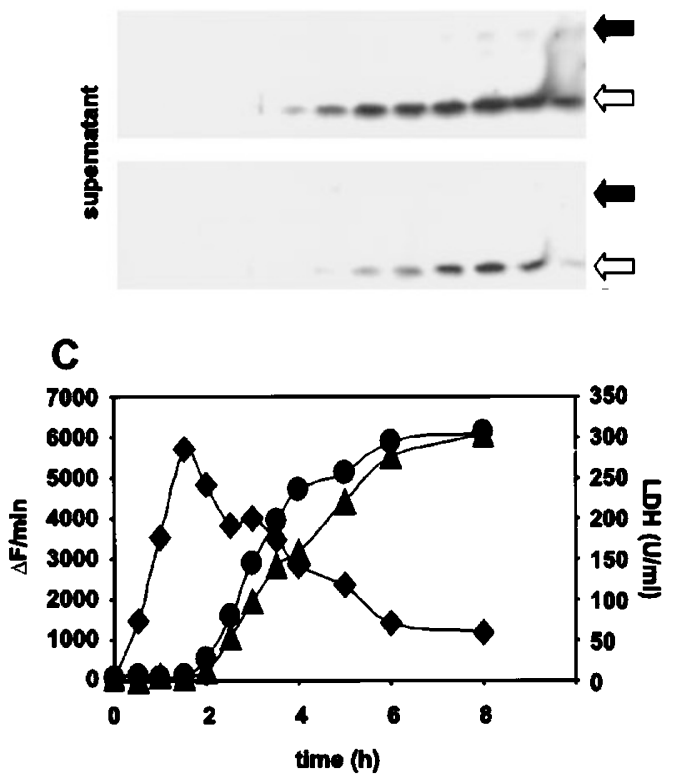

D TNF $\begin{array}{lllllllllllll}0 & 1 & 2 & 3 & 4 & 6 & 8 & 16 & 20 & 24 & 32 & 42 & h\end{array}$

caspase-3

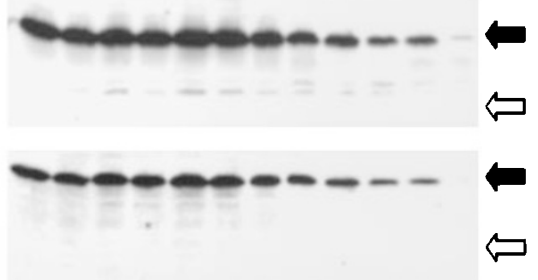

E
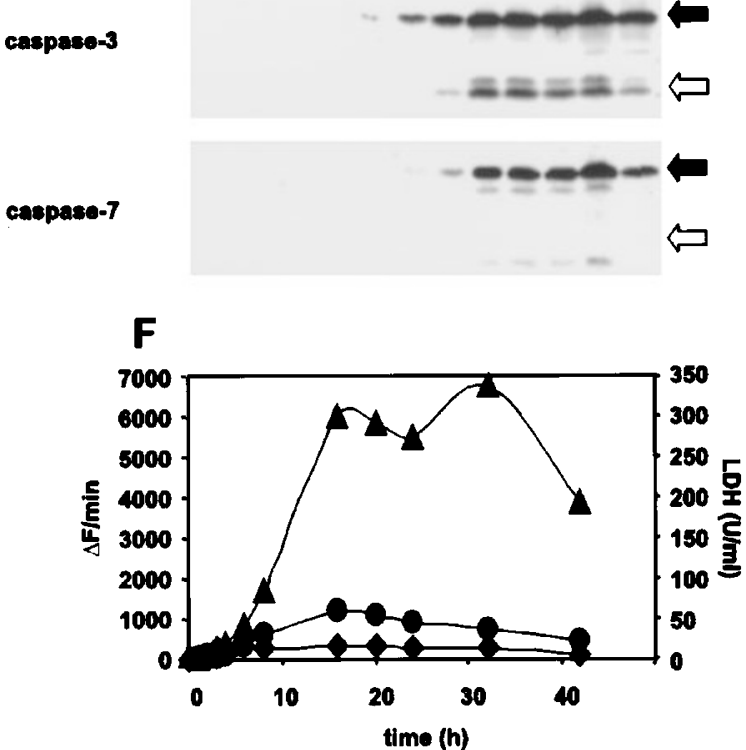

Figure 3 Time kinetic analysis of caspases-3 and -7 processing, DEVDase activity and LDH release in culture supernatant during anti-Fas-induced apoptosis and TNF-induced necrosis. Total cell lysates were prepared and the culture supernatant was precipitated. The presence of caspase-3 and caspase-7 in lysate (A, D) and supernatant (B, E) was determined by PAGE and Western blotting. Open and closed arrows indicate processed p20 subunit and procaspase, respectively. In a parallel set-up, the presence of Ac-DEVD-amc cleavage activity in cytosol $(\bullet)$, and supernatant $(\mathbf{O})$, as well as of LDH in supernatant $(\mathbf{A})$ was determined $(\mathbf{C}, \mathbf{F})$

cytochrome $c$ accumulated in the culture supernatant from the moment that cells had lost their plasma membrane integrity (Figure 4E).

As a control for the release of mitochondrial intermembrane proteins we also analyzed the release of AK2 from the mitochondria. AK2 in healthy cells is confined to the mitochondrial intermembrane space. AK2 is released during etoposide-, anti-Fas- and staurosporine-induced apoptosis in Jurkat cells. ${ }^{38,39}$ Release of AK2 during anti-Fas-induced apoptosis in L929sAhFas cells occurs later than release of cytochrome $c$ (Figure 4C), which might suggest that cytochrome $c$ is more rapidly accessible for release than AK2. During TNF-induced necrosis, AK2 is not, or only in very small amounts, detectable in the cytosol (Figure 4F). AK2 is detectable in the supernatant of necrotically dying cells from the moment that cells have lost their plasma membrane integrity, as is the case for detection of cytochrome $c$ (data not shown). To examine whether the inner mitochondrial membrane was damaged during necrosis, we checked the presence of AK3. AK3 is located exclusively in the mitochondrial matrix. ${ }^{40}$ AK3 was undetected in the cytosol and in the supernatant of apoptotic or necrotic cells (data not shown). Moreover, the amount of matrix AK3 in the organelle fraction remained unchanged, also at time points when cells had completely lost their cell membrane integrity, suggesting that the inner mitochondrial membrane remains intact during both apoptosis and necrosis.

\section{Influence of Bcl-2 overexpression on apoptosis, necrosis, and cytochrome $c$ release}

$\mathrm{Bcl}-2$ delays apoptotic cell death by different stimuli. ${ }^{15}$ Scaffidi et al. $^{41}$ demonstrated the existence of two pathways of antiFas-induced apoptosis. Type I apoptosis is independent of pro-apoptotic factors released by mitochondria and is not inhibited by Bcl-2. Type II apoptosis depends on the release of proapoptotic factors from the mitochondria and is inhibited by $\mathrm{Bcl}-2$. It has also been reported that $\mathrm{Bcl}-2$ inhibits necrotic cell death induced by oxygen depletion, respiratory chain inhibitors, or by glutathione depletion. ${ }^{42-44}$ Therefore, we analyzed the effect of $\mathrm{Bcl}-2$ overexpression on anti-Fas- and 
A

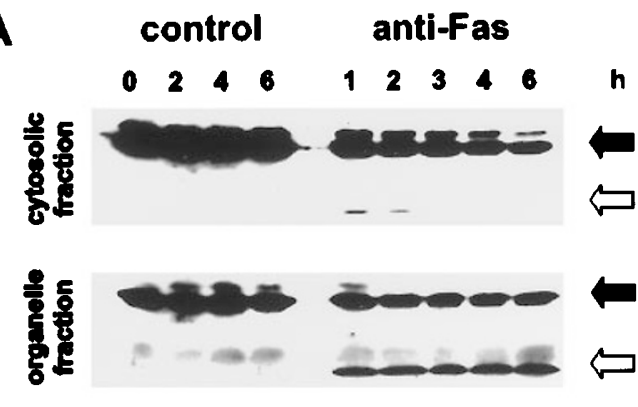

B

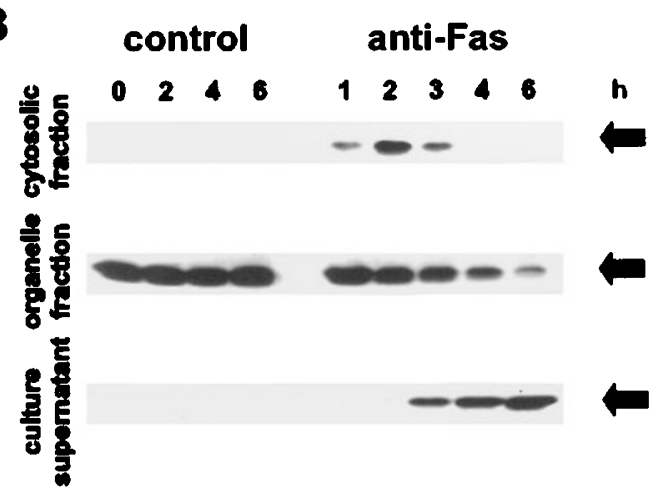

D control TNF

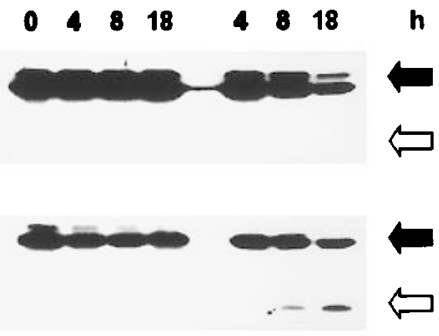

E

control TNF
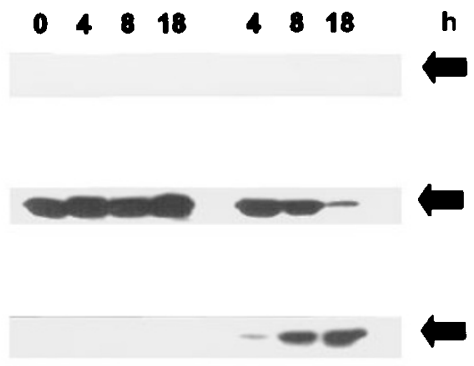

C

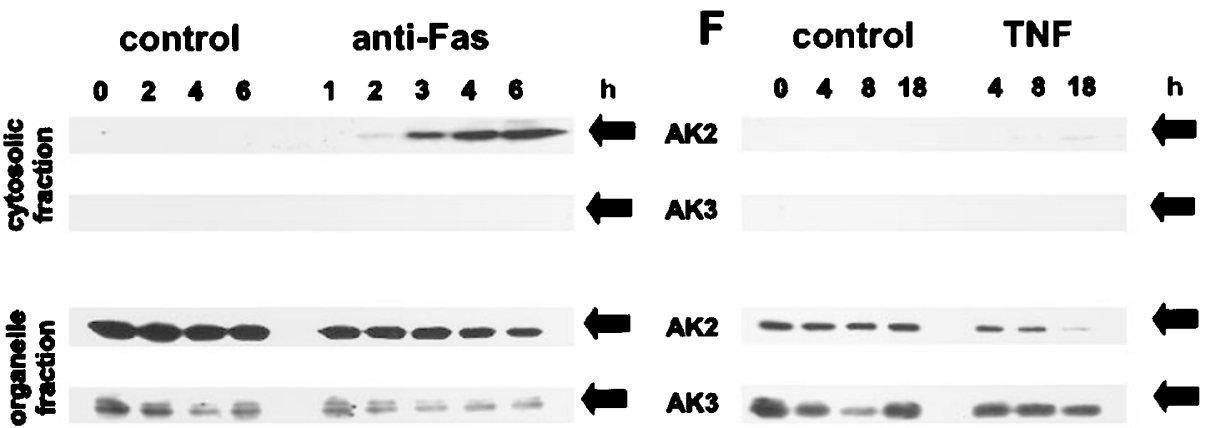

Figure 4 Time kinetic analysis of the proteolytic activation of Bid (A, D), cellular distribution of cytochrome $c(\mathbf{B}, \mathbf{E})$, AK2 and AK3 (C, F), during anti-Fas-induced apoptosis and TNF-induced necrosis. Cytosolic and organelle fractions were prepared and analyzed by Western blotting. Closed and open arrows indicate fulllength Bid and tBid, respectively. Cell death was determined by PI uptake (shown in Figure $2 \mathrm{C}$ and F)

TNF-induced cell death. L929sAhFas.Bcl-2 cells were generated, and clones were selected based on human Bcl-2 and human Fas receptor expression (Figure 5A). The cytotoxic response of Bcl-2-transfected cells was examined by the loss of plasma membrane integrity. Overexpression of $\mathrm{Bcl}-2$ delayed consistently for about $1 \mathrm{~h}$ anti-Fas-induced apoptotic cell death as compared to control L929sAhFas cells, which displayed $100 \%$ secondary necrosis at $3 \mathrm{~h}$ (Figure 5B). TNF-induced necrosis was delayed for about $4 \mathrm{~h}$ (Figure $5 \mathrm{C}$ ), while $100 \%$ plasma membrane permeabilization of control cells was seen at $12 \mathrm{~h}$. These results indicate that overexpression of $\mathrm{Bcl}-2$ temporarily prevents both apoptosis and necrosis. Overexpression of $\mathrm{Bcl}-2$ also delays the release of cytochrome $c$ after anti-Fas treatment (Figure
5B) and allows its prolonged accumulation in the cytosol, probably due to delay in secondary necrosis.

\section{Role of ROS and serine proteases during apoptosis and necrosis}

When L929sAhFas cells are preincubated with ZVAD-fmk prior to anti-Fas treatment, caspase activity and apoptotic cell death are completely prevented. However, pretreatment with zVAD-fmk does not prevent cell death, as cells rapidly die in a typical necrotic way. ${ }^{45}$ TNF-induced necrosis can be blocked by addition of BHA, a lipophilic oxygen radical scavenger. ${ }^{46}$ As clear from Figure $6 \mathrm{~A}$, necrosis induced by the combined addition of ZVAD-fmk and anti-Fas is blocked by pretreatment 
A
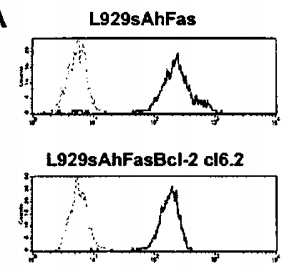

L929sAhFas.Bcl-2 cl6.11

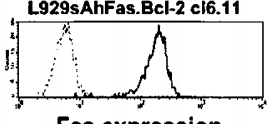

Fas expression

B

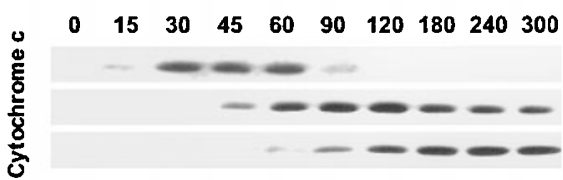

L929sAhFas

L929SAhFasBcl-2 c16.2

L929sAhFas.Bcl-2 cl6.11

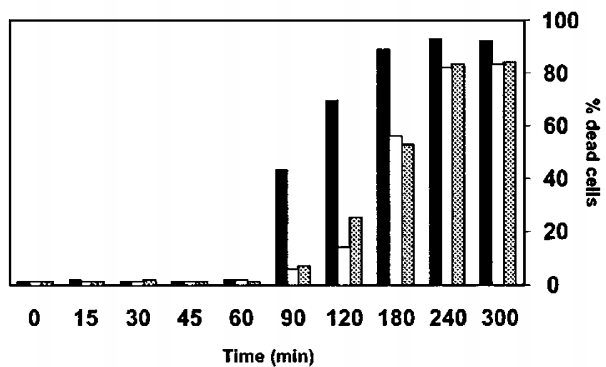

C

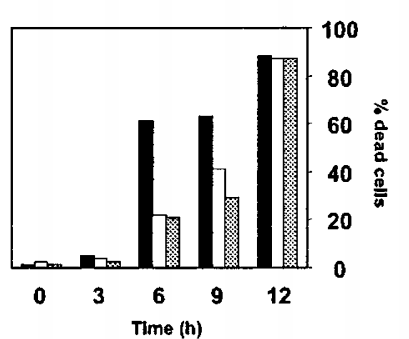

Figure 5 Time kinetic analysis of cell death in Bcl-2-overexpressing cells during anti-Fas-induced apoptosis and TNF-induced necrosis. L929sA cells were transfected sequentially with Bcl-2 and Fas. (A) Western blot analysis of $\mathrm{Bcl}-2$ expression and FACS analysis of Fas expression. (B) Amount of cytochrome $c$ released in the cytosol and percentage of cells that had lost plasma membrane integrity during anti-Fas-induced apoptosis in L929sAhFas (black bars), L929sAhFas.Bcl-2 cl6.2 (white bars) and L929sAhFas.Bcl-2 cl6.11 (grey bars) cells. (C) Percentage of cells that had lost plasma membrane integrity during TNF-induced necrosis

with BHA. BHA did not affect apoptotic cell death induced by anti-Fas treatment alone.

It has been reported that serine proteases are implicated in TNF-induced cytotoxicity in 2929 cells. $^{47}$ Therefore, we tested the effect of the serine protease inhibitors TPCK and TLCK on both types of cell death (Figure 6B). The results clearly demonstrate that necrosis induced by both TNF and anti-Fas in the presence of zVAD-fmk is inhibited by TPCK, but not by TLCK, suggesting common cell death pathways by both death receptors. The apoptotic process induced by anti-Fas was not influenced by administration of TPCK.
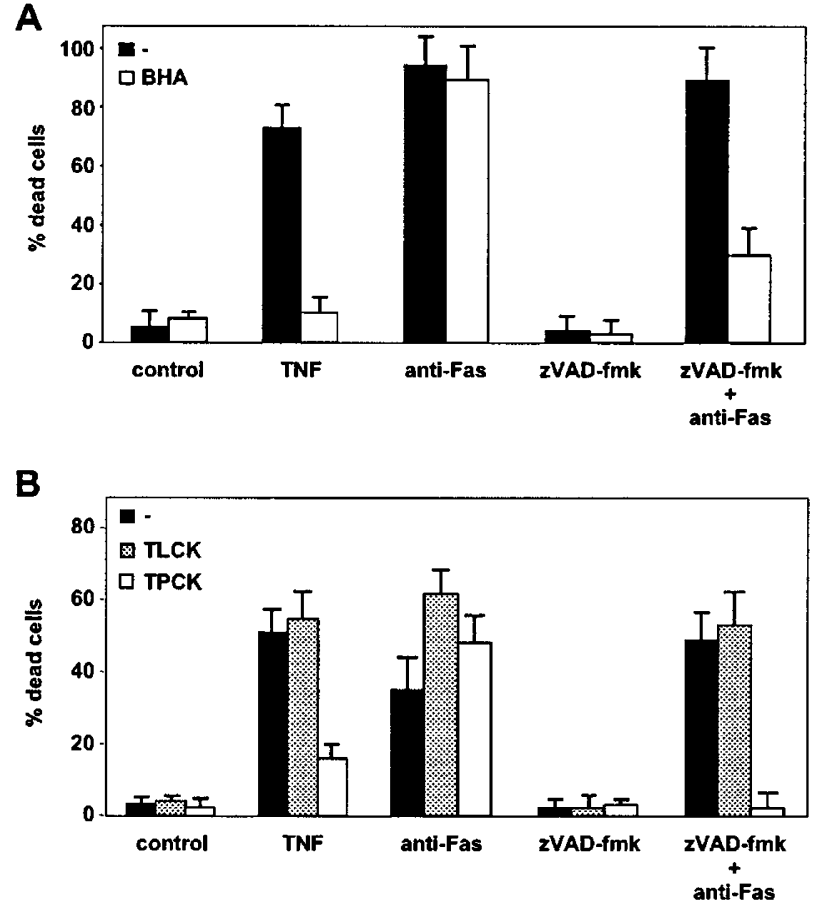

Figure 6 Effect of BHA, TLCK and TPCK on death receptor-induced apoptosis and necrosis in L929sAhFas cells. (A) Cells were preincubated for $2 \mathrm{~h}$ with or without $\mathrm{BHA}(100 \mu \mathrm{M})$; the percentage of dead cells was determined with PI. (B) Cells were preincubated for $2 \mathrm{~h}$ with or without TLCK $(300 \mu \mathrm{M})$ or TPCK $(50 \mu \mathrm{M})$; the percentage of dead cells was determined with MTT. Where indicated, cells were co-pretreated with zVAD-fmk $(25 \mu \mathrm{M})$. The percentage of cell death was measured after $6 \mathrm{~h}$ in the case of TNF treatment and after $4 \mathrm{~h}$ in the case of anti-Fas treatment

\section{Discussion}

Caspases are indispensable as initiators and effectors of the apoptotic cell death program. However, evidence is accumulating that inhibition of the classical caspase-dependent apoptotic pathway leads in many cases to necrotic-like cell death, which is essentially caspase-independent. ${ }^{26,27}$ Thus, the same cell death stimulus can result in apoptotic or necrotic cell death, depending on whether procaspases are activated or not. In this study, we compared in the same cellular context caspase-dependent apoptosis and caspase-independent necrosis initiated by the p55 TNF receptor (TNF-RI) and Fas, both DD receptors. When stimulated with anti-Fas, L929sAhFas cells die apoptotically, accompanied by procaspases-3 and -7 activation, both in the cytosol and the organelle fraction. When the same cells are treated with TNF or with the combination of ZVAD-fmk and anti-Fas, necrotic cell death is induced but caspase activity is not detected.

A common starting point for necrotic signaling between both $\mathrm{DD}$ receptors could be their $\mathrm{DD}$, as it was shown that the TNF-RI DD is sufficient to induce necrosis in L929 cells. ${ }^{48}$ Another common starting point for both cell death pathways is the adapter protein FADD, as it has been shown that in the absence of procaspase-8, FADD signals to necrosis. ${ }^{28,49}$ Structure/function analysis by transient overexpression in different cell lines revealed that the DD of 
FADD is cytotoxic in L929sA cells, which die from necrosis after TNF treatment. In cell lines that die apoptotically after TNF exposure the DD of FADD is not cytotoxic; moreover it acts as a dominant negative inhibitor of apoptotic cell death induced by TNF. ${ }^{33}$ These results suggest that the common initiator between TNF-RI- and Fas-induced necrosis is the DD of FADD. In Jurkat cells necrotic signaling by death domain receptor has been pinpointed on the kinase activity of RIP $^{31}$ and the death effector domain of FADD. ${ }^{32}$ How both reports can be reconciled is unclear at the moment. Moreover, our finding that transient overexpression of the death domain of FADD is sufficient to induce cell death in L929sA cells while it protects against TNF and anti-Fas mediated cell death in apoptotic dying cells, ${ }^{33}$ suggests that initiation of necrosis might involve multiple adaptors, depending on the cell type. In this study we report that, in contrast to apoptosis, necrosis is not dependent on caspase activation; rather, low levels of constitutively active (pro)caspases, below detection limits, might even play a protective role. ${ }^{30}$ The protective role of caspases in necrotic systems is suggested by the observation that pretreatment with z-VAD-fmk or overexpression of CrmA, which have a preferential inhibitory activity for caspases-1, $-8,-9$, and caspases- 1 and -8 , respectively, ${ }^{50}$ strongly synergize TNF-RI-mediated necrosis. ${ }^{45}$ Caspase-8-deficient Jurkat cells are also more sensitive to necrotic cell death induced by overexpression of dimerizable FADD. ${ }^{28}$ Possibly, low levels of enzymatic activity of caspases are implied in controlling TNF- or anti-Fas-induced ROS formation during necrosis, as inhibition of caspases leads to enhanced and accelerated ROS formation. ${ }^{29,30,45,49}$ In this respect, we show that $\mathrm{BHA}$, a ROS scavenger, can protect against necrotic cell death induced by combined addition of z-VAD-fmk and anti-Fas, as reported previously for TNF. 46,51 Anti-Fas-induced apoptosis is also accompanied by ROS formation (data not shown), but this does not contribute to the apoptotic cytotoxicity, as BHA does not protect Fas-mediated apoptosis. It is also possible that active caspase-8 generated in the receptosome complex decreases necrotic and anti-apoptotic signaling by proteoIysis of RIP and provides in this way a positive feedback loop for apoptosis. ${ }^{52}$ We further demonstrate that addition of the serine protease inhibitor TPCK protects L929sAhFas cells against caspase-independent necrotic cell death by a combined addition of anti-Fas plus zVAD-fmk, whereas TPCK has no effect on anti-Fas-induced apoptotic cell death. This suggests that serine proteases might play a decisive role in necrotic cell death both induced by TNF and by a combined addition of anti-Fas plus zVAD-fmk.

The molecular link between the death receptors and the mitochondria is given by proteolysis of Bid. The C-terminal p15 fragment of Bid translocated from the cytosol to the mitochondria, where it elicits release of cytochrome $c .^{7,8,53}$ Full-length (p22) Bid is mainly cytosolic, ${ }^{54}$ although it was recently shown that during apoptosis p22 Bid can also associate with the mitochondria. ${ }^{55}$ Our results show that tBid, once activated, rapidly translocated to the organelle fraction, where it probably remains associated with the mitochondrial outer membrane. Alternatively, organelleassociated p22 Bid might be a direct target for caspase-8 or other organelle-associated caspases, as it has been shown that also caspase- 3 is able to proteolyze p22 Bid. ${ }^{56}$ The appearance of tBid during the early phase of anti-Fasinduced apoptosis was subsequently followed by a rapid release of cytochrome $c$ from the mitochondrial intermembrane space in the cytosol, occurring clearly before cells had lost their plasma membrane integrity. Furthermore, the release of cytochrome $c$ was delayed in Bcl-2-overexpressing L929sAhFas cells, resulting in a slower apoptotic response. During TNF-induced necrosis, we could not detect any cytochrome $c$ in the cytosol fraction. However, cytochrome $c$ was immediately released in the culture supernatant, coinciding with release of cytochrome $c$ from the organelle fraction and loss of plasma membrane integrity. This suggests passive diffusion of cytosolic proteins, a process also observed during the secondary necrotic phase of anti-Fas-stimulated L929sAhFas cells. Overexpression of $\mathrm{Bcl}-2$ also delayed TNF-mediated necrotic cell death. As there is no early release of cytochrome $c$ in the case of necrosis, Bcl-2 must exert its protective effect by another molecular mechanism. In this respect, it was demonstrated that BNIP3, a proapoptotic $\mathrm{Bcl}-2$ family member that interacts with $\mathrm{Bcl}-2$ and $\mathrm{Bcl}-\mathrm{X}_{\mathrm{L}}$ in a BH3-independent way, ${ }^{57}$ causes a decrease in the mitochondrial transmembrane potential without release of cytochrome $c$ or nuclear translocation of AIF. ${ }^{58}$ It is possible that the anti-necrotic action of $\mathrm{Bcl}-2$ is exerted by complexation with BNIP3. An alternative mechanism of action of $\mathrm{Bcl}-2$ might be its ability to prolong the integrity of mitochondrial oxidative phosphorylation. ${ }^{59,60}$ As TNFinduced necrosis has been attributed to superoxide anion production due to electron overflow at complex $\mathrm{I},{ }^{51,61}$ it is indeed possible that the Bcl-2-dependent delay of TNFinduced necrosis is due to a Bcl-2-mediated modulation of the oxidative phosphorylation pathway. Bcl-2 has also been reported to have direct anti-oxidant functions, but the molecular mechanism is still unclear. ${ }^{62-64}$ It has been shown that overexpression of $\mathrm{Bcl}-2$, although elevating the basal levels of hydrogen peroxide, nevertheless restricted the excessive production of hydrogen peroxide induced by apoptotic stimuli, such as TNF. ${ }^{65}$

Finally, we demonstrate that during anti-Fas-elicited secondary necrosis mainly active caspases are released to the culture supernatant. In the case of TNF-induced necrosis, only procaspases are detectable in the culture supernatant. At later time points of necrotic cell death, some processed caspases were found. These findings correlate with the massive accumulation of DEVDase activity during apoptosis and only minor during necrosis. The absence of procaspases in the apoptotic supernatant suggests that released procaspases are rapidly proteolyzed by active caspases in an autoamplifying cascade. Surprisingly, in the case of necrosis almost no extracellular proteolytic processing of procaspases-3 and -7 occurs. This would imply that other cytosolic or lysosomal proteases released during plasma membrane and organelle disintegration during the late stages of necrosis might not be able to proteolyze these procaspases or are inactive under the conditions tested. This profound extracellular difference between apoptotically and necrotically dying cells 
might result in differential pericellular responses. The physiological implications of the release of caspases are currently unknown. However, one may imagine that extracellular active caspases play a modulatory role on inflammation, be it positive or negative. This could be of pathophysiological relevance in the case of massive apoptosis or insufficient phagocytic capacity.

Our results demonstrate that apoptosis and necrosis, although initiated by the same DD receptors, involve separate signaling pathways in which caspases and mitochondrial parameters are differentially implicated. Necrosis, as defined by the absence of DNA hypoploidy, cytoplasmic swelling and rapid plasma membrane permeabilization, is essentially a caspase-independent process in which serine proteases and mitochondria reactive oxygen production play an essential role. Another distinctive parameter is the absence of active caspase release in the case of necrosis, which might have important pathophysiological implications. However, many questions remain unanswered regarding the precise molecular signaling events leading to DD receptor-mediated necrosis. At the moment different adaptors and domains have been implicated, which might reflect cellular differences. Until now, the necrotic cell death process can merely be discussed in negative terms with the well-studied apoptotic pathways as a reference. Further research on defined models will be required to elucidate the necrotic cell death pathway as clearly distinct or interrelated with the apoptotic cell death pathway and to define the executioner processes during cell death by necrosis.

\section{Materials and Methods}

\section{Antibodies, cytokines and reagents}

Recombinant human TNF was produced in Escherichia coli and purified to at least $99 \%$ homogeneity in the Ghent laboratory. The specific biological activity was $9.4 \times 10^{7} \mathrm{lU} / \mathrm{mg}$ as determined in a standardized cytotoxicity assay on L929sA cells. Anti-human Fas antibody (clone 2R2) was purchased from Cell Diagnostica (Münster, Germany). Butylated hydroxyanisole (BHA), N-tosyl-L-phenylalanine chloromethylketone (TPCK) and N-tosyl-L-lysine chloromethylketone (TLCK) were purchased from Sigma Chemical Co. (St. Louis, MO, USA). Propidium iodide (PI; Becton Dickinson, San Jose, CA, USA) was dissolved at $3 \mathrm{mM}$ in PBS and was used at $30 \mu \mathrm{M}$. Annexin Vfluorescein isothiocyanate (FITC) was obtained from PharMingen (San Diego, CA, USA). The fluorescent markers chloromethyltetramethylrosamine (CMTMros) and rhodamine 123 (R123) were purchased from Molecular Probes (Eugene, OR, USA), prepared as a $1 \mathrm{mM}$ stock solution in DMSO and used at 0.05 and $0.1 \mu \mathrm{M}$, respectively. The caspase peptide inhibitor zVAD-fmk was purchased from Bachem (Bubendorf, Switzerland). The caspase fluorogenic substrates acetylAsp(OMe)-Glu(OMe)-Val-Asp(OMe)-aminomethylcoumarin (AcDEVD-amc) and acetyl-Tyr-Val-Ala-Asp-aminomethylcoumarin (AcYVAD-amc) were obtained from Peptide Institute (Osaka, Japan). Antibodies to cytochrome $c$ and human $\mathrm{Bcl}-2$ were obtained from PharMingen (San Diego, CA, USA) and antibodies to human/mouse Bid from R\&D Systems (Minneapolis, MN, USA). Rabbit polyclonal antibodies against recombinant murine caspases ${ }^{66}$ were prepared at the Centre d'Economie Rurale (Laboratoire d'Hormonologie Animale,
Marloie, Belgium). All anti-caspase antibodies used recognized both procaspase and cleaved p20 subunits (our own unpublished results). Adenylate kinase (AK) 2 and AK3 antibodies were kindly provided by Dr. T Noma (Department of Biochemistry, Yamaguchi University School of Medicine, Yamaguchi, Japan).

\section{Cell culture}

L929sA is a murine fibrosarcoma cell line, derived from L929, which was selected for its sensitivity to the cytotoxic activity of TNF and cultured as described previously. ${ }^{67}$ L929sA was transfected with the human Fas receptor (L929sAhFas) as described previously. ${ }^{29}$ L929sAhFas.Bcl-2 cells were obtained by consecutive transfection of human Bcl-2 cDNA, using neomycine as a selection marker, followed by transection of human Fas cDNA, using puromycine as a selection marker. Human $\mathrm{Bcl}-2 \mathrm{cDNA}$ was kindly provided by $\mathrm{Dr}$. $\mathrm{J}$ Reed (Burnham Institute, La Jolla, CA, USA) ${ }^{68}$ and was inserted as an EcoRI-EcoRI fragment in pCAGGS. ${ }^{69}$ Expression of the transfected genes was controlled by flow fluorocytometry and Western blotting of cell lysates (anti-human Fas antibody and anti-human Bcl-2 antibody, respectively).

\section{Induction of apoptosis or necrosis for FACS analysis and Western blotting}

For flow fluorocytometric analysis, L929sAhFas or L929sAhFas.Bcl2 cells were kept in suspension by seeding them at $1.5 \times 10^{5} \mathrm{cells} / \mathrm{ml}$ per well the day before analysis in uncoated 24-well tissue culture plates (Sarstedt, Newton, NC, USA) in serum-containing DMEM medium. For Western analysis, cells were seeded at $5 \times 10^{5}$ cells $/ \mathrm{ml}$ per well the day before analysis in 6-well tissue culture plates. The next day, antiFas $(250 \mathrm{ng} / \mathrm{ml})$ or TNF $(10000 \mathrm{IU} / \mathrm{ml})$ were added to the cells.

\section{Flow fluorocytometric analysis of $\Delta \Psi_{\mathrm{m}}$, cell membrane alterations and hypoploidy}

The decrease in $\Delta \Psi_{\mathrm{m}}$ was analyzed using the fluorogenic probe CMTMros. The exposure of phosphatidylserine (PS) at the cell surface was analyzed with annexin V-FITC as detailed previously. ${ }^{70}$ The loss of cell membrane integrity was determined by means of the PI exclusion method. ${ }^{71}$ The percentage of cells containing hypoploid DNA was determined by PI staining of cells after one freeze-thaw cycle to permeabilize cells, as described previously. ${ }^{72}$

\section{Fluorogenic substrate assay for caspase activity}

The fluorogenic substrate assay for caspase activity was carried out as described previously. ${ }^{29}$ Briefly, $1.5 \times 10^{5} \mathrm{cells} / \mathrm{ml}$ were treated with TNF (10 $000 \mathrm{lU} / \mathrm{ml})$ or anti-Fas $(250 \mathrm{ng} / \mathrm{ml})$. Cells were washed in cold phosphate buffer and lysed in $200 \mu \mathrm{l} \mathrm{NP}-40$ lysis buffer. Caspase activity was determined by incubating $25 \mu \mathrm{g}$ of cell lysate with $50 \mu \mathrm{M}$ Ac-YVAD-amc or Ac-DEVD-ame in $200 \mu \mathrm{l}$ cell-free system buffer. The release of fluorescent 7-amino-4-methylcoumarin was measured for $60 \mathrm{~min}$ at 2-min intervals by fluorometry (excitation at $360 \mathrm{~nm}$ and emission at $480 \mathrm{~nm}$ ) (Cytofluor; PerSeptive Biosystems, Cambridge, MA, USA); the maximal rate of increase in fluorescence was calculated $(\Delta \mathrm{F} / \mathrm{min})$.

\section{Lactate dehydrogenase (LDH) assay}

LDH measurements were performed with a Hitachi 747 automated analyzer (Roche Molecular Biochemicals Basel, Switzerland), based 
on conversion of pyruvate to lactate and simultaneous oxidation of $\mathrm{NADH}$ to NAD. The rate of decrease in NADH is directly proportional to the LDH activity and is determined spectrophotometrically at $340 \mathrm{~nm}$.

\section{3-(4,5-dimethylthiazol-2-yl)-2,5-diphenyltetrazolium bromide (MTT) assay}

Cells were seeded the day before at $2 \times 10^{4}$ cells/well in 96-well plates. The next day inhibitors, TNF and anti-Fas were added at the given concentrations. Cell death was assessed at different time intervals using MTT staining as described previously. ${ }^{73}$ The percentage of cell death was calculated using the equation $100 \% \times\left[1-\left(A_{595 / 655}\right.\right.$ treated cells $-A_{595 / 655}$ medium $) /\left(A_{595 / 655}\right.$ untreated cells $-A_{595 / 655}$ medium)].

\section{Western blot analysis}

$5 \times 10^{5} \mathrm{ml}$ cells seeded in 6-well plates in serum-free DMEM supplemented with insulin, transferring and selenium were treated with or without TNF $(10000 \mathrm{IU} / \mathrm{ml})$ or anti-Fas $(250 \mathrm{ng} / \mathrm{ml})$. The proteins present in the culture supernatant were precipitated with $10 \%$ trichloracetic acid. Cells were washed in cold phosphate buffer and permeabilized with $250 \mu \mathrm{l} 0.02 \%$ digitonin dissolved in cell-free system buffer and left on ice for $1 \mathrm{~min}$. This treatment allows selective lysis of the plasma membrane without affecting the organelle membranes. After centrifugation, the supernatant and the pellet (organelle fraction) were dissolved separately in Laemmli buffer and analyzed by $15 \%$ SDS - PAGE and Western blotting using antibodies to cytochrome $c$, Bid, AK2, AK3, caspases-3 and -7 and developed by ECL-based detection (Nycomed Amersham, Little Chalfont, UK).

\section{Acknowledgements}

Research was supported by the Interuniversitaire Attractiepolen, the Fonds voor Wetenschappelijk Onderzoek-Vlaanderen (grant No. G005097N and 3G000601), and an EC-RTD grant No. QLRT-19900739. D Vercammen is a postdoctoral researcher and G Brouckaert is a predoctoral researcher with the Fonds voor Wetenschappelijk Onderzoek-Vlaanderen. G Denecker was supported by Kom op tegen Kanker. $M$ Steemans and $T$ Vanden Berghe are predoctoral researchers with the Vlaams Instituut voor de Bevordering van het Wetenschappelijktechnologisch Onderzoek in de Industrie. G Van Loo is paid by the Flanders Interuniversity Institute for Biotechnology. The authors thank $A$ Meeus and $W$ Burm for technical assistance with tissue culture. B Zhivotovsky was supported by the Swedish Cancer Society.

\section{References}

1. Sun XM, MacFarlane M, Zhuang J, Wolf BB, Green DR and Cohen GM (1999) Distinct caspase cascades are initiated in receptor-mediated and chemicalinduced apoptosis. J. Biol. Chem. 274: 5053-5060

2. Wallach D, Varfolomeev EE, Malinin NL, Goltsev YV, Kovalenko AV and Boldin MP (1999) Tumor Necrosis Factor Receptor and Fas signaling Mechanisms. Annu. Rev. Immunol. 17: 331-367

3. Boldin MP, Varfolomeev EE, Pancer Z, Mett IL, Camonis JH and Wallach D (1995) A novel protein that interacts with the death domain of Fas/APO1 contains a sequence motif related to the death domain. J. Biol. Chem. 270 : 7795-7798

4. Muzio M, Chinnaiyan AM, Kischkel FC, O'Rourke K, Shevchenko A, Ni J, Scaffidi C, Bretz JD, Zhang M, Gentz R, Mann M, Krammer PH, Peter ME and Dixit VM (1996) FLICE, a novel FADD-homologous ICE/CED-3-like protease, is recruited to the CD95 (Fas/APO-1) death-inducing signaling complex. Cell 85: 817-827
5. Muzio M, Stockwell BR, Stennicke HR, Salvesen GS and Dixit VM (1998) An induced proximity model for caspase-8 activation. J. Biol. Chem. 273: $2926-$ 2930

6. Liu X, Kim CN, Yang J, Jemmerson R and Wang X (1996) Induction of apoptotic program in cell-free extracts: requirement for dATP and cytochrome c. Cell 86: $147-157$

7. LiH, Zhu H, Xu CJ and Yuan J (1998) Cleavage of BID by caspase 8 mediates the mitochondrial damage in the Fas pathway of apoptosis. Cell 94: 491-501

8. LuoX, Budihardjol, Zou H, Slaughter Cand Wang X (1998) Bid, a Bcl2 interacting protein, mediates cytochrome $c$ release from mitochondria in response to activation of cell surface death receptors. Cell 94: 481-490

9. Steemans M, Goossens V, Van de Craen M, Van Herreweghe F, Vancompernolle K, De Vos K, Vandenabeele P and Grooten J (1998) A caspase-activated factor (CAF) induces mitochondrial membrane depolarization and cytochrome c release by a nonproteolytic mechanism. J. Exp. Med. 188: 2193-2198

10. Zou H, Henzel WJ, Liu X, Lutschg A and Wang X (1997) Apaf-1, a human protein homologous to $\mathrm{C}$. elegans CED-4, participates in cytochrome c-dependent activation of caspase-3 [see comments]. Cell 90: $405-413$

11. Srinivasula SM, Ahmad M, Fernandes-Alnemri T and Alnemri ES (1998) Autoactivation of procaspase-9 by Apaf-1-mediated oligomerization. Mol. Cell 1: 949-957

12. Hu Y, Benedict MA, Ding L and Núñez G (1999) Role of cytochrome c and dATP/ ATP hydrolysis in Apaf-1-mediated caspase-9 activation and apoptosis. EMBO J. 18: $3586-3595$

13. Bernardi P, Scorrano L, Colonna R, Petronilli V and Di Lisa F (1999) Mitochondria and cell death. Mechanistic aspects and methodological issues. Eur. J. Biochem. 264: $687-701$

14. Vander Heiden MG, Chandel NS, Williamson EK, Schumacker PT and Thompson CB (1997) Bcl-xL regulates the membrane potential and volume homeostasis of mitochoncria [see comments]. Cell 91: 627-637

15. Gross A, McDonnell JM and Korsmeyer SJ (1999) BCL-2 family members and the mitochondria in apoptosis. Genes Dev. 13: 1899-1911

16. Fadok VA, Bratton DL, Rose DM, Pearson A, Ezekewitz RA and Henson PM (2000) A receptor for phosphatidylserine-specific clearance of apoptotic cells. Nature 405: 85-90

17. Miwa K, Asano M, Horai R, Iwakura Y, Nagata S and Suda T (1998) Caspase 1independent IL-1 beta release and inflammation induced by the apoptosis inducer Fas ligand. Nat. Med. 4: 1287-1292

18. Daemen VA, van't Veer C, Denecker G, Heemskerk VH, Wolfs TG, Clauss M,Vandenabeele $P$ and Buurman WA (1999) Inhibition of apoptosis induced by ischemia-reperfusion prevents inflammation. J. Clin. Invest. 104: 541-549

19. Knies UE, Behrensdorf HA, Mitchell CA, Deutsch U, Risau W, Drexler HCA and Clauss M (1998) Regulation of endothelial monocyte-activating polypeptide II release by apoptosis. Proc. Natl. Acad. Sci. USA 95: 12322-12327

20. Behrensdorf HA, van de Craen M, Knies UE, Vandenabelle $P$ and Clauss $M$ (2000) The endothelial monocyte-activating polypeptide II (EMAP II) is a substrate for caspase-7. FEBS Lett. 466: 143-147

21. Dypbukt JM, Ankarcrona M, Burkitt M, Sjoholm A, Strom K, Orrenius $S$ and Nicotera P (1994) Different prooxidant levels stimulate growth, trigger apoptosis, or produce necrosis of insulin-secreting RINm5F cells. The roel of intracellular polyamines. J. Biol. Chem. 269: 30553-30560

22. Bonfoco E, Krainc D, Ankarcrona M, Nicotera P and Lipton SA (1995) Apoptosis and necrosis: two distinct events induced, respectively, by mild and intense insults with $\mathrm{N}$-methyl-D-aspartate or nitric oxide/superoxide in cortical cell cultures. Proc. Natl. Acad. Sci. USA 92: 7162-7166

23. Vantieghem A, Assefa Z, Vandenabelle $P$, Declercq W, Courtois $S$, Vandenheede JR, Merlevede W, de Witte $P$ and Agostinis $P$ (1998) Hypericininduced photosensitization of HeLa cells leads to apoptosis or necrosis. Involvement of cytochrome $\mathrm{c}$ and procaspase-3 activation in the mechanism of apoptosis. FEBS Lett. 440: 19-24

24. Eguchi Y, Shimizu S and Tsujimoto Y (1997) Intracellular ATP levels determine cell death fate by apoptosis or necrosis. Cancer Res 57: 1835-1840

25. Leist M, Single B, Castoldi AF, Kühnle S and Nicotera P (1997) Intracellular adenosine triphosphate (ATP) concentration: a switch in the decision between apoptosis and necrosis. J. Exp. Med. 185: 1481-1486

26. Borner $C$ and Monney $L$ (1999) Apoptosis without caspases: an inefficient molecular guillotine? Cell Death Differ. 6: 497-507 
27. Kitanaka C and Kuchino Y (1999) Caspase-independent programmed cell death with necrotic morphology. Cell Death Differ. 6: 508-515

28. Kawahara A, Ohsawa Y, Matsumura H, Uchiyama Y and Nagata S (1998) Caspase-independent cell killing by Fas-associated protein with death domain. J. Cell Biol. 143: 1353-1360

29. Vercammen D, Brouckaert G, Denecker G, Van de Craen M, Declercq W, Fiers W and Vandenabeele P (1998) Dual signaling of the Fas receptor: initiation of both apoptotic and necrotic cell death pathways. J. Exp. Med. 188: $919-930$

30. Fiers W, Beyaert R, Declercq W and Vandenabeele P (1999) More than one way to die: apoptosis, necrosis and reactive oxygen damage. Oncogene 18: 77197730

31. Holler N, Zaru R, Micheau O, Thome M, Attinger A, Valitutti S, Bodmer JL, Schneider P, Seat B and Tschopp J (2000) Fas triggers an alternative, caspase8-independent cell death pathway using the kinase RIP as effector molecule. Nat. Immunol. 1: 489-495

32. Matsumura H, Shimizu Y, Ohsawa $Y$, Kawahara A, Uchiyama $Y$ and Nagata $S$ (2000) Necrotic death pathway in Fas receptor signaling. J. Cell Biol. 151: 1247 1256

33. Boone E, Vanden Berghe T, Van Loo G, De Wilde G, De Wael N, Vercammen D Fiers W, Haegeman G and Vandenabeele P (2000) Structure/Function analysis of 55 tumor necrosis factor receptor and fas-associated death domain. Effect on necrosis in L929sA cells. J. Biol. Chem. 275: 37596-37603

34. Johnson DE (2000) Noncaspase proteases in apoptosis. Leukemia 14: 16951703

35. Wang KK (2000) Calpain and caspase: can you tell the difference? Trends. Neurosci. 23: 20-26

36. Martin SJ, Reutelingsperger CP, McGahon AJ, Rader JA, van Schie RC, LaFace DM and Green DR (1995) Early redistribution of plasma membrane phosphatidylserine is a general feature of apoptosis regardless of the initiating stimulus: inhibition by overexpression of Bcl-2 and Abl. J. Exp. Med. 182: 15451556

37. Earnshaw WC, Martins LM and Kaufmann SH (1999) Mammalian caspases: Structure, Activation, Substrates, and Functions During Apoptosis. Annu. Rev. Biochem. 68: 383-424

38. Single B, Leist M and Nicotera P (1998) Simultaneous release of adenylate kinase and cytochrome $c$ in cell death [letter]. Cell Death Differ. 5: 10011003

39. Köhler C, Gahm A, Noma T, Nakazawa A, Orrenius S and Zhivotovsky B (1999) Release of adenylate kinase 2 from the mitochondrial intermembrane space during apoptosis. FEBS Lett. 447: 10-12

40. Nobumoto M, Yamada M, Song S, Inouye S and Nakazawa A (1998) Mechanism of mitochondrial import of adenylate kinase isozymes. J. Biochem. (Tokyo) 123: $128-135$

41. Scaffidi C, Fulda S, Srinivasan A, Friesen C, Li F, Tomaselli KJ, Debatin KM, Krammer PH and Peter ME (1998) Two CD95 (APO-1/Fas) signaling pathways. EMBO J. 17: 1675-1687

42. Kane DJ, Ord T, Anton R and Bredesen DE (1995) Expression of bcl-2 inhibits necrotic neural cell death. J. Neurosci. Res. 40: 269-275

43. Shimizu S, Eguchi Y, Kamiike W, Itoh Y, Hasegawa J, Yamabe K, Otsuki Y, Matsuda $H$ and Tsujimoto $Y$ (1996) Induction of apoptosis as well as necrosis by hypoxia and predominant prevention of apoptosis by Bcl-2 and Bcl-XL. Cancer Res. 56: 2161-2166

44. Shimizu S, Eguchi Y, Kamiike W, Waguri S, Uchiyama Y, Matsuda H and Tsujimoto $Y(1996)$ Retardation of chemical hypoxia-induced necrotic cell death by $\mathrm{Bcl}-2$ and ICE inhibitors: possible involvement of common mediators in apoptotic and necrotic signal transductions. Oncogene 12: 2045-2050

45. Vercammen D, Beyaert R, Denecker G, Goossens V, Van Loo G, Declercq W, Grooten J, Fiers W and Vandenabeele P (1998) Inhibition of caspases increases the sensitivity of L929 cells to necrosis mediated by tumor necrosis factor. J. Exp. Med. 187: 1477-1485

46. Goossens V, Grooten J, De Vos K and Fiers W (1995) Direct evidence for tumor necrosis factor-induced mitochondrial reactive oxygen intermediates and their involvement in cytotoxicity. Proc. Natl. Acad. Sci. USA 92: 8115-8119

47. Suffys P, Beyaert R, Van Roy F and Fiers W (1988) Involvement of a serine protease in tumour-necrosis-factor-mediated cytotoxicity. Eur. J. Biochem. 178: $257-265$
48. Vandevoorde V, Haegeman G and Fiers W (1997) Induced expression of trimerized intracellular domains of the human tumor necrosis factor (TNF) p55 receptor elicits TNF effects. J. Cell Biol. 137: 1627-1638

49. Khwaja $A$ and Tatton $L$ (1999) Resistance to the cytotoxic effects of tumor necrosis factor alpha can be overcome by inhibition of a FADD/Caspasedependent signaling pathway. J. Biol. Chem. 274: 36817-36823

50. Ekert PG, Silke J and Vaux DL (1999) Caspase inhibitors. Cell Death Differ. 6 : $1081-1086$

51. Schulze-OsthoffK, Beyaert R, Vandevoorde V, Haegeman G and Fiers W (1993) Depletion of the mitochondrial electron transport abrogates the cytotoxic and gene-inductive effects of TNF. EMBO J. 12: 3095-3104

52. Martinou JC, Desagher S and Antonsson B (2000) Cytochrome c release from mitochondria: all or nothing. Nat. Cell. Biol. 2: E41-E43

53. Gross A, Yin XM, Wang K, Wei MC, Jockel J, Milliman C, Erdjument-Bromage $H$, Tempst $P$ and Korsmeyer SJ (1999) Caspase cleaved BID targets mitochondria and is required for cytochrome crelease, while $B C L-X L$ prevents this release but not tumor necrosis factor-R1/Fas death. J. Biol. Chem. 274: 1156-1163

54. Wang K, Yin XM, Chao DT, Milliman CL and Korsmeyer SJ (1996) BID: a novel BH3 domain-only death agonist. Genes Dev. 10: 2859-2869

55. Desagher S, Osen-Sand A, Nichols A, Eskes R, Montessuit S, Lauper S, Maundrell K, Antonsson B and Martinou JC (1999) Bid-induced conformational change of Bax is responsible for mitochondrial cytochrome $c$ release during apoptosis. J. Cell Biol. 144: 891-901

56. Slee EA, Keogh SA and Martin SJ (2000) Cleavage of BID during cytotoxic drug and UV radiation-induced apoptosis occurs downstream of the point of $\mathrm{Bcl}-2$ action and is catalysed by caspase-3: a potential feedback loop for amplification of apoptosis-associated mitochondrial cytochrome c release. Cell Death Differ. 7: $556-565$

57. Ray R, Chen G, Vande Velde C, Cizeau J, Park JH, Reed JC, Gietz RD and Greenberg AH (2000) BNIP3 heterodimerizes with $\mathrm{Bcl}-2 / \mathrm{Bcl}-\mathrm{X}(\mathrm{L})$ and induces cell death independent of a $\mathrm{Bcl}-2$ homology $3(\mathrm{BH} 3)$ domain at both mitochondrial and nonmitochondrial sites. J. Biol. Chem. 275: 1439-1448

58. Vande Velde C, Cizeau J, Dubik D, Alimonti J, Brown T, Israels S, Hakem R and Greenberg AH (2000) BNIP3 and genetic control of necrosis-like cell death through the mitochondrial permeability transition pore. Mol. Cell Biol. 20:5454 5468

59. Green DR and Reed JC (1998) Mitochondria and apoptosis. Science 281: 1309-1312

60. Shimizu S, Eguchi Y, Kamiike W, Funahashi Y, Mignon A, Lacronique V, Matsuda $\mathrm{H}$ and Tsujimoto $\mathrm{Y}$ (1998) Bcl-2 prevents apoptotic mitochondrial dysfunction by regulating proton flux. Proc. Natl. Acad. Sci. USA 95: 14551459

61. Goossens V, Stange G, Moens K, Pipeleers D and Grooten J (1999) Regulation of tumor necrosis factor-induced, mitochondria- and reactive oxygen speciesdependent cell death by the electron flux through the electron transport chain complex I. Antioxidants \& Redox Signaling 1: 285-295

62. Hockenbery DM, Oltvai ZN, Yin XM, Milliman CL and Korsmeyer SJ (1993) Bcl-2 functions in an antioxidant pathway to prevent apoptosis. Cell 75: 241-251

63. Jacobson MD and Raff MC (1995) Programmed cell death and Bcl-2 protection in very low oxygen. Nature 374: 814-816

64. Shimizu S, Eguchi Y, Kosaka H, Kamiike W, Matsuda H and Tsujimoto Y (1995) Prevention of hypoxia-induced cell death by Bcl-2 and Bcl-xL. Nature 374:811 813

65. Esposti MD, Hatzinisiriou I, McLennan H and Ralph S (1999) Bcl-2 and mitochondrial oxygen radicals. New approaches with reactive oxygen speciessensitive probes. J. Biol. Chem. 274: 29831-29837

66. Van de Craen M, Declercq W, Van den Brande I, Fiers W and Vandenabeele P (1999) The proteolytic procaspase activation network: an in vitro analysis. Cell Death Differ. 6: 1117-1124

67. Vanhaesebroeck B, Decoster E, Van Ostade X, Van Bladel S, Lenaerts A, Van Roy $\mathrm{F}$ and Fiers W (1992) Expression of an exogenous tumor necrosis factor (TNF) gene in TNF-sensitive cell lines confers resistance to TNF-mediated cell lysis. J. Immunol. 148: 2785-2794

68. Reed JC, Cuddy M, Haldar S, Croce C, Nowell P, Makover D and Bradley K (1990) BCL2-mediated tumorigenicity of a human T-lymphoid cell line: synergy with MYC and inhibition by BCL2 antigsense. Proc. Natl. Acad. Sci. USA 87: $3660-3664$ 
69. Niwa H, Yamamura K and Miyazaki J (1991) Efficient selection for highexpression transfectants with a novel eukaryotic vector. Gene 108: 193-199

70. Denecker G, Dooms H, Van Loo G, Vercammen D, Grooten J, Fiers W, Declerca W and Vandenabeele $P(2000)$ Phosphatidyl serine exposure during apoptosis precedes release of cytochrome $c$ and decrease in mitochondrial transmembrane potential. FEBS Lett. 465: 47-52

71. Nicoletti I, Migliorati G, Pagliacci MC, Grignani F and Riccardi C (1991) A rapid and simple method for measuring thymocyte apoptosis by propidium iodide staining and flow cytometry. J. Immunol. Methods 139: 271-279
72. Vercammen D, Vandenabeele P, Beyaert R, Declercq W and Fiers W (1997) Tumour necrosis factor-induced necrosis versus anti-Fas-induced apoptosis in L929 cells. Cytokine 9: $801-808$

73. TadaH, Shiho O, KuroshimaK, Koyama Mand Tsukamoto K(1986) An improved colorimetric assay for interleukin 2. J. Immunol. Methods 93: 157-165 